\title{
Erratum: ASCertaining cytoskeletal rearrangements in antigen presentation and migration
}

Ioannis Karakasiliotis \& Dimitris L Kontoyiannis

Nat. Immunol. 12, 923-925 (2011); published online 20 September 2011; corrected after print 1 June 2012

The Nature Immunology article to which this News and Views refers has an associated addendum. We want to inform readers that some of the comments made in this News \& Views, although made in good faith on the basis of the article's conclusions, may no longer be valid.

\section{Erratum: TGF- $\beta$ is responsible for NK cell immaturity during ontogeny and increased susceptibility to infection during mouse infancy}

Jeffrey P Marcoe, James R Lim, Keri L Schaubert, Nassima Fodil-Cornu, Marsel Matka, Alexandra L McCubbrey, Alexander R Farr, Silvia M Vidal \& Yasmina Laouar

Nat. Immunol. 13, 843-850 (2012); published online 5 August 2012; corrected after print 15 January 2013

In the version of this article initially published, the key in Figure 4e was omitted. The correct key defines "Expression (fold)" as red (-4) to green (4). The error has been corrected in the HTML and PDF versions of the article.

\section{Erratum: Sensing and alarm function of resident memory CD8 ${ }^{+} T$ cells}

Jason M Schenkel, Kathryn A Fraser, Vaiva Vezys \& David Masopust

Nat. Immunol. 14, 509-513 (2013); published online 31 March 2013; corrected online 8 April 2013

In the version of this article initially published, a label in Figure $2 \mathrm{~b}$ and the scale size for Figure $5 \mathrm{a}$ were incorrect. The left label under the left image in Figure 2b should be CXCL9 (in red); the legend for Figure 5a should end "Scale bars, $20 \mu \mathrm{m}$." The errors have been corrected in the HTML and PDF versions of this article.

\section{Erratum: Can DCs be distinguished from macrophages by molecular} signatures?

David A Hume, Neil Mabbott, Sobia Raza \& Tom C Freeman

Nat. Immunol. 14, 187-189 (2013); published online 15 February 2013; corrected after print 22 April 2013

In the version of this article initially published, the first URL in the third paragraph was incorrect. The correct URL is http://www.macrophages. com/HumeNI2013. The error has been corrected in the HTML and PDF versions of the article.

\section{Erratum: The chemotactic receptor EBI2 regulates the homeostasis, localization and immunological function of splenic dendritic cells}

Dominique Gatto, Katherine Wood, Irina Caminschi, Danielle Murphy-Durland, Peter Schofield, Daniel Christ, Gunasegaran Karupiah \& Robert Brink

Nat. Immunol. 14, 446-453 (2013); published online 17 March 2013; corrected after print 22 April 2013

In the version of this article initially published, the top graph in Figure $7 \mathrm{~g}$ was incorrect. The error has been corrected in the HTML and PDF versions of the article. 